\title{
PENINGKATAN SELF-DIRECTED LEARNING READINESS MAHASISWA DALAM MATA KULIAH FOTOGRAFI DASAR MELALUI FLIPPED CLASSROOM DAN ICT
}

\author{
Putra Uji Deva Satrio ${ }^{1}$, Athika Dwi Wiji Utami ${ }^{2}$ \\ ${ }^{1,2}$ Universitas Nahdlatul Ulama Sidoarjo \\ E-mail: 1jqhero19@gmail.com, ${ }^{2}$ athikautami@gmail.com
}

\begin{abstract}
Penelitian ini menggunakan pendekatan kualitatif dengan metode Lesson Study berbasis Classroom Action Research. Kegiatan Lesson Study mencakup 3 tahap kegiatan dalam satu siklus yaitu Plan, Do, dan See selama 3 siklus yang melibatkan dua dosen observer. Hasil Lesson Study menunjukkan bahwa pelaksanaan Lesson Study selama 3 siklus ini, antara lain : (1) Suasana perkuliahan menjadi "lebih hidup" ditunjukkan oleh meningkatnya keaktifan belajar mahasiswa selama 3 siklus tersebut; (2) Penerapan Flipped classroom meningkatkan kesiapan mahasiswa dalam mengikuti perkuliahan, yang dapat dilihat dari adanya peningkatan keaktifan dan kesiapan mahasiswa pada setiap siklusnya saat berada pada sesi tanya jawab dan diskusi kelompok; (3) Terjadi perubahan pola pembelajaran dosen berupa semakin mengurangi penggunaan ceramah dan menambah variasi metode serta penggunaan media; (4) Semua dosen yang terlibat baik dosen model maupun dosen observer ada kecenderungan semakin bisa bekerja sama dengan teman sejawat ,semakin terbuka dalam mengemukakan kekurangan, dan semakin berkeinginan untuk selalu meningkatkan kualitas pembelajarannya; dan (5) Tanggapan mahasiswa terhadap penerapan flipped classroom berbantu ICT terhadap kemandirian mahasiswa pada perkuliahan Fotografi Dasar adalah positif.
\end{abstract}

Keywords: Self Directed Learning Readiness, Fotografi Dasar, Flipped Classroom, Lesson Study

\section{INTRODUCTION}

Era revolusi industri 4.0 merupakan era digitalisasi, optimasi dan kustomisasi produksi, adaptasi, interaksi antara manusia dan mesin, automatic data exchange and communication, serta penggunaan teknologi informasi. Era ini berpengaruh besar terhadap perubahan karakteristik kebutuhan di dunia usaha dan industri dan perilaku masyarakat pada umumnya. Perguruan tinggi sebagai sebuah wadah untuk mempersiapkan dan menghasilkan generasi penerus bangsa, wajib merespon tantangan tersebut dengan tepat. Perguruan tinggi diharap dapat menjawab tantanganuntuk menghadapi kemajuan teknol ogi dan persaingan dunia kerja di era globalisasi, dengan menghasilkan lulusan yang terampil dalam aspek literasi data, literasi teknologi dan literasi manusia [1]. Literasi Data merupakan kemampuan untuk membaca, analisis, dan menggunakan informasi (Big Data) di dunia digital, Literasi Teknologi merupakan kemampuan memahami cara kerja mesin, aplikasi teknologi (Coding, Artificial Intelligence, \& Engineering Principles), dan Literasi Manusia berhubungan dengan humanities, komunikasi, \& desain [2]. Perguruan tinggi harus mengubah kurikulum dengan pendekatan human digital dan keahlian berbasis digital. Selain itu, perguruan tinggi harus dapat memfasilitasi life-long learning. Perguruan tinggi harus dapat memberikan fasilitas selama proses pendidikan agar dapat menghasilkan individu yang memiliki kesiapan belajar mandiri, dikenal sebagai self directed learning readiness (SDLR). SelfDirected Learning (SDL) mencakup proses yang berupa apa saja yang diinginkan dari pembelajaran (individual learning needs), karakteristik belajar (individual learning characteristics), dan aktivitas belajar mandiri (self-directed learning activities) untuk 
mencapai learning satisfaction [5]. SDL seems to be dependent on the readines of a learner, a content and the context of learning, rather than on the age of the learner [4]. SDL tergantung pada kesiapan mahasiswa itu sendiri, konten dan konteks pembelajaran, bukanlah pada faktor usia. SDL dapat dihubungkan dengan life-long learning, dimana karekteristik ini dibutuhkan mahasiswa dalam menghadapi tantangan era revolusi industri 4.0.

Beberapa solusi pembelajaran yang dapat diaplikasikan dalam sebuah perguruan tinggi untuk menghadapi tantangan tersebut adalah blended learning. Pemanfaatan ICT dalam proses perkuliahan diharapkan dapat membantu tujuan perkuliahan lebih cepat tercapai secara efektif dan efisien. Selain itu, dampak yang diharapkan bagi mahasiswa adalah semakin meningkatnya literasi mahasiswa terhadap ICT dan sumber pembelajaran dan adanya perubahan perilaku mahasiswa menjadi lebih aktif, responsif, dan mandiri.

Flipped Classroom model
pembelajaran yang "membalik"
tradisional, di mana biasanya materi diberikan di kelas dan siswa mengerjakan tugas di rumah. Konsep Flipped Classroom mencakup active learning, keterlibatan siswa, dan podcasting. Dalam flipped classroom, materi terlebih dahulu diberikan melalui video pembelajaran yang harus ditonton siswa di rumah masing-masing. Sebaliknya, sesi belajar di kelas digunakan untuk diskusi kelompok dan mengerjakan tugas. Di sini, guru berperan sebagai pembina atau pemberi saran [3]. Edmodo merupakan sebuah platform yang menghubungkan mahasiswa dengan dosen secara terorganisir dalam aktifitas perkuliahan secara online, mulai dari akses tugas, nilai, diskusi, pemberian materi, dan informasi yang berkaitan dengan perkuliahan.

Dengan pemanfaatan edmodo dalam perkuliahan melalui pendekatan Flipped classroom, diharapkan mahasiswa sebelum mengikuti perkuliahan dapat lebih siap secara pemahaman awal mengenai materi yang akan diajarkan, sehingga saat perkuliahan terjadi mahasiswa dapat lebih aktif dan pemahaman mengenai materi bisa lebih mendalam. Selain itu, diharapkan dengan treatment ini, mahasiswa dapat lebih memiliki kesiapan belajar mandiri.

\section{METHOD}

1. Jenis Penelitian

Penelitian ini menggunakan pendekatan kualitatif dengan metode Lesson Study berbasis Classroom Action Research. Lesson Study dilaksanakan dalam suatu rangkaian kegiatan yang disebut siklus, terdiri dari 3 tahap kegiatan, tahap pertama Plan (merencanakan) tahap kedua Do (melaksanakan), dan tahap ketiga See (merefleksi) selama 3 (tiga) siklus. Pada model penelitian ini, dosen model (peneliti) berkalaborasi dengan dua orang dosen dari kelompok rumpun yang sama sebagai observer selama 3 siklus ini.

Dosen observer terlibat aktif dalam proses perencanaan perkuliahan (Plan), pelaksanaan saat di kelas (do), dan refleksi (see) hasil temuan saat pelaksanaan di kelas. Saat pelaksanaan tahap do, dosen observer mengisi lembar observasi yang berisi pertanyaan mengenai fenomena yang terjadi selama perkuliahan terjadi. Saat refleksi, dosen model dan observer berdiskusi mengenai temuan-temuan yang didapat oleh dosen observer, menyimpulkan seberapa efektifkan perkuliahan pada pertemuan hari itu, dan saran dari temuan-temuan negatif untuk perbaikan siklus selanjutnya.

\section{Subyek Penelitian}

Subyek penelitian ini adalah 19 mahasiswa angkatan 2018 kelas A Program Studi Desain Komunikasi Visual, Fakultas Ilmu Komputer, Universitas Nahdlatul Ulama Sidoarjo, yang memprogram mata kuliah Fotografi Dasar pada semester gasal tahun ajaran 2018/2019. 


\section{Teknik dan Instrumen Pengumpulan Data}

Pengumpulan data menggunakan teknik observasi. Observasi dilakukan oleh dosen observer menggunakan lembar observasi didukung dengan alat perekam (handycamp, kamera, dsb). Instrumen pengumpulan data menggunakan lembar observasi. Selain itu, instrumen pengumpulan data lainnya berupa tanggapan mahasiswa terhadap penerapan Flipped classroom berbantu ICT terhadap kemandirian mahasiswa yang bersangkutan yang menggunakan angket dengan skala likert.

\section{Teknik Analisis Data}

Data yang terkumpul dianalisis secara deskriptif kualitatif menghasilkan deskripsi tentang kajian pembelajaran yang dilaksanakan oleh dosen model, temuantemuan yang bermanfaat digunakan untuk melakukan perbaikan pada pembelajaran selanjutnya.

\section{Prosedur Penelitian}

Lesson Study dilaksanakan melalui 3 tahap kegiatan, tahap pertama Plan (merencanakan) tahap kedua Do (melaksanakan), dan tahap ketiga See (merefleksi) pada 3 siklus.

a. Siklus 1: Plan

Pada tahap Plan, diskusi dipimpin oleh

Ketua Program Studi dan diawali dengan penyampaian RPP dan penjelasan detail oleh dosen model mengenai materi, model pembelajaran, dan rencana perkuliahan lainnya pada siklus pertama. Materi perkuliahan yang akan dibahas pada siklus I adalah pengantar fotografi dan genre fotografi dengan menggunakan pendekatan Flipped Classrom berbantu Edmodo untuk menjelaskan konsep dan tampilan Video. Mahasiswa sebelum perkuliahan berlangsung diminta untuk mengakses edmodo untuk mengerjakan tugas awal berdasarkan video yang sudah diberikan di edmodo. Pada perkuliahan berlangsung dilakukan diskusi dan pendalaman materi melalui tugas pendalaman yang dikumpulkan melalui edmodo.

b. Siklus 1 : Do

Kegiatan sesebelum perkuliahan (seminggu sebelum perkuliahan) adalah mahasiswa mengakses edmodo dan mengerjakan tugas awal tentang materi yang akan diberikan saat perkuliahan. Pada saat perkuliahan berlangsung, berikut rincian pelaksanaannya:

1) Dosen menyampaikan pengantar (tujuan pembelajaran, kompetensi dan garis besar materi)

2) Dosen dan mahasiswa membahas tugas awal yang diberikan melalui edmodo.

3) Dosen mengonfirmasi mengenai tugas awal tersebut. Mahasiswa dipersilahkan melakukan tanya jawab.

4) Pada pendalaman materi, dosen membagi mahasiswa dalam kelompok kecil.

5) Mahasiswa mengerjakan tugas praktek kamera dan dosen membimbing secara individu.

6) Beberapa perwakilan melakukan presentasi terhadap hasil diskusi.

7) Umpan balik hasil pengerjaan praktek kamera mahasiswa.

8) Dosen menutup perkuliahan dengan memberikan tugas untuk dikumpulkan minggu depan melalui edmodo.

\section{c. Siklus 1: See}

Kegiatan ini merupakan refleksi untuk mengkaji pelaksanaan Do yang dihadiri oleh dosen model dan dosen observer. Pada tahap ini, secara bergantian dosen model menyampaikan refleksi pelaksanaan pembelajarannya dan dilanjutkan dengan penyampaian hasil pengamatan oleh kedua dosen observer. Diskusi dilakukan antara dosen model dan observer untuk membahas temuan yang terjadi dan saran membangun untuk siklus berikutnya. Berikut hasil refleksi:

1) Mahasiswa yang berada di bagian belakang kurang mengikuti kegiatan, terutama 3 mahasiswa di bagian pojok 
tidak memperhatikan dosen dan presentasi.

2) Dosen lebih sering berada di depan dan kurang memperhatikan mahasiswa yang di belakang. Mahasiswa kurang mendapatkan kesempatan untuk eksplorasi materi dan kurang mendapat kesempatan menggunakan kamera.

3) Pertanyaan dosen dapat mengaktifkan mahasiswa.

4) Setting kelas diperbaiki, misal menggunakan letter $U$ agar kondisi kelas lebih kondusif dan meminimalisir mahasiswa yang tidak konsentrasi terhadap materi perkuliahan.

5) Mahasiswa masih belum siap untuk mengikuti perkuliahan dilihat dari jumlah mahasiswa yang mengerjakan tugas awal siklus I dan saat pengerjaan tugas kelompok masih ada beberapa mahasiswa yang pasif di kelompoknya.

\section{Siklus 2 : Plan}

Pada tahap Plan, diskusi dipimpin oleh Ketua Program Studi dan diawali dengan penyampaian RPP dan penjelasan detail oleh dosen model mengenai materi, model pembelajaran, dan rencana perkuliahan lainnya pada siklus kedua. Materi perkuliahan yang akan dibahas pada siklus II adalah jenisjenis lensa dan genre fotografi dengan menggunakan pendekatan Flipped Classrom berbantu Edmodo untuk menjelaskan konsep dan tampilan Video. Mahasiswa sebelum perkuliahan berlangsung diminta untuk mengakses edmodo untuk mengerjakan tugas awal berdasarkan video yang sudah diberikan di edmodo. Pada perkuliahan berlangsung dilakukan diskusi dan pendalaman materi melalui tugas pendalaman yang dikumpulkan melalui edmodo. Berdasarkan hasil refleksi siklus I, beberapa masukan untuk perbaikan perkuliahan di siklus II, antara lain pada pengaturan kelas dimana tempat duduk dibagi menjadi dua bagian sebalah kiri dan kanan sehingga membentuk huruf 'U'.

\section{Siklus $2:$ Do}

Kegiatan sesebelum perkuliahan (seminggu sebelum perkuliahan) adalah mahasiswa mengakses edmodo dan mengerjakan tugas awal tentang materi yang akan diberikan saat perkuliahan. Pada saat perkuliahan berlangsung, berikut rincian pelaksanaannya :

1) Dosen menyampaikan pengantar (tujuan pembelajaran, kompetensi dan garis besar materi.

2) Dosen bertanya tentang pengerjaan tugas pendalaman kuliah siklus I, dan meminta perwakilan mahasiswa untuk memberikan laporannya secara lisan di depan kelas, beberapa mahasiswa meminta dosen memberikan penjelasan tentang kesulitan yang dihadapi.

3) Dosen dan mahasiswa membahas tugas awal siklus II yang diberikan melalui edmodo.

4) Dosen mengonfirmasi mengenai tugas awal tersebut. Terjadi umpan balik antara dosen dan mahasiswa.

5) Dosen menjelaskan materi menggunakan metode ceramah dibantu video pembelajaran mengenai materi pertemuan hari ini. Umpan balik antara dosen dan mahasiswa mengenai materi tersebut. Dosen bertanya kepada mahasiswa secara bergilir dan meminta mahasiswa mencari contoh konkrit.

6) Pada pendalaman materi, dosen membagi mahasiswa dalam 4 kelompok kecil. Mahasiswa mengerjakan tugas praktek kamera mengenai jenis-jenis lensa dan Dosen berkeliling mendatangi mahasiswa untuk memberi bantuan.

7) Pengerjaan latihan selsesai, dosen mempersilahkan mahasiswa yang sudah selesai mengerjakan menyampaikan hasil pekerjaannya dari masing-masing kelompok. Perwakilan mahasiswa yang maju mewakili masing-masing kelompok secara bergiliran untuk mempresentasikan hasil praktek.

8) Dosen memberikan balikan terhadap hasil presentasi mahasiswa dan menyimpulkan bersama-sama mahasiswa.

9) Dosen memberikan tugas pendalaman 
untuk dikerjakan di luar kelas dan menyampaikan materi yang akan dibahas untuk pertemuan berikutnya.

\section{Siklus 2 : See}

Kegiatan ini merupakan refleksi untuk mengkaji pelaksanaan Do yang dihadiri oleh dosen model dan dosen observer. Pada tahap ini, secara bergantian dosen model menyampaikan refleksi pelaksanaan pembelajarannya dan dilanjutkan dengan penyampaian hasil pengamatan oleh kedua dosen observer. Diskusi dilakukan antara dosen model dan observer untuk membahas temuan yang terjadi dan saran membangun untuk siklus berikutnya. Berikut hasil refleksi

1) Dosen model sudah berupaya aktif membentuk mahasiswa yang berani untuk berpendapat, percaya diri, karena motivasi dan konsentrasi mahasiswa belum optimal.

2) Terlihat ada peningkatan yang signifikan terutama berkaitan dengan kesiapan dan keaktifan mahasiswa dalam mengikuti materi pembelajaran yang diketahui dari kegiatan dan jawaban saat mendatangi tiap kelompok dan mempertanyakan progress hasil praktek foto.

3) Tugas-tugas mahasiswa sangat membantu dalam memahami materi.

4) Untuk memancing perhatian mahasiswa lebih aktif dan masuk dalam bahasan/materi saat permulaan kelas menentukan keberlangsungan proses pembelajaran yang direncanakan.

5) Pengaturan kelas dengan huruf U lebih efektif membangun kelas kondusif.

\section{Siklus 3 : Plan}

Pada tahap Plan, diskusi dipimpin oleh Ketua Program Studi dan diawali dengan penyampaian RPP dan penjelasan detail oleh dosen model mengenai materi, model pembelajaran, dan rencana perkuliahan lainnya pada siklus kedua. Materi perkuliahan yang akan dibahas pada siklus III adalah Ruang Tajam Sempit dan Ruang Tajam Lebar dengan menggunakan pendekatan Flipped Classrom berbantu Edmodo untuk menjelaskan konsep dan tampilan Video. Mahasiswa sebelum perkuliahan berlangsung diminta untuk mengakses edmodo untuk mengerjakan tugas awal berdasarkan video yang sudah diberikan di edmodo. Pada perkuliahan berlangsung dilakukan diskusi dan pendalaman materi melalui tugas pendalaman yang dikumpulkan melalui edmodo.

\section{Siklus 3 : Do}

Kegiatan sesebelum perkuliahan (seminggu sebelum perkuliahan) adalah mahasiswa mengakses edmodo dan mengerjakan tugas awal tentang materi yang akan diberikan saat perkuliahan. Pada saat perkuliahan berlangsung, berikut rincian pelaksanaannya :

1) Dosen bertanya tentang pengerjaan tugas pendalaman kuliah siklus II, dan meminta perwakilan mahasiswa untuk memberikan laporannya secara lisan di depan kelas, beberapa mahasiswa meminta dosen memberikan penjelasan tentang kesulitan yang dihadapi.

2) Dosen dan mahasiswa membahas tugas awal siklus III yang diberikan melalui edmodo.

3) Dosen mengonfirmasi mengenai tugas awal tersebut. Terjadi umpan balik antara dosen dan mahasiswa.

4) Dosen membuka pembelajaran dengan menyampaikan materi yang akan dibahas dan kompetensi yang harus dimiliki mahasiswa pada siklus III.

5) Dosen menjelaskan materi menggunakan metode ceramah dibantu video pembelajaran mengenai materi pertemuan hari ini. Umpan balik antara dosen dan mahasiswa mengenai materi tersebut.

6) Dosen meminta/menunjuk beberapa mahasiswa untuk menjawab pertanyaan.

7) Pada pendalaman materi, dosen membagi mahasiswa dalam 4 kelompok kecil. Mahasiswa mengerjakan tugas diskusi kamera mengenai Ruang Tajam Sempit 
dan Ruang Tajam Lebar dan Dosen berkeliling mendatangi mahasiswa untuk memberi bantuan.

8) Perwakilan kelompok mahasiswa mempresentasikan hasil diskusi kemudian dilanjutkan dengan tanggapan dari kelompok lain.

9) Dosen melakukan klarifikasi terhadap hasil diskusi mahasiswa dan menyimpulkan perkuliahan pada siklus III bersama-sama mahasiswa. Perkuliahan ditutuk dengan pemberian memberikan tugas untuk dibahas minggu depan melalui Edmodo.

\section{Siklus 3 : See}

Kegiatan ini merupakan refleksi untuk mengkaji pelaksanaan Do yang dihadiri oleh dosen model dan dosen observer. Pada tahap ini, secara bergantian dosen model menyampaikan refleksi pelaksanaan pembelajarannya dan dilanjutkan dengan penyampaian hasil pengamatan oleh kedua dosen observer. Diskusi dilakukan antara dosen model dan observer untuk membahas temuan yang terjadi dan saran membangun untuk siklus berikutnya. Berikut hasil refleksi

1) Ada beberapa mahasiswa datang terlambat.

2) Pada saat menjelaskan materi hendaknya dosen tidak terpaku hanya berada di depan saja.

3) Dosen lebih baik dalam memanajemen waktu agar pengerjaan tuga kepada mahasiswa tidak terlalu menyita waktu.

4) Dibandingkan siklus I dan II, kondisi kelas lebih kondusif. Semua mahasiswa yang mengerjakan tugas awal pada siklus ini. Mahasiswa terlihat lebih siap dalam mengikuti perkuliahan yang dilihat dari sesi tanya jawab dan diskusi yang kondusif.

\section{RESULTS AND DISCUSSION}

\section{Plan}

Rencana pembelajaran sudah menggunakan pendekatan Flipped classroom dengan pemanfaatan ICT seperti Edmodo dan video. Pada setiap Plan dirancang dengan memperbaiki Plan sebelumnya mengacu pada temuan-temuan dari dosen observer dan hasil see pada siklus sebelumnya. Pada siklus ketiga terlihat adanya peningkatan kesiapan dosen model, kesiapan mahasiswa, serta suasana kelas terlihat lebih kondusif dan aktif.

\section{Do}

Pada siklus 1, masih ditemukan kendala seperti mahasiswa pasif dan tidak mengerjakan tugas awal. Secara keseluruhan pelaksanaan do pada siklus 1 berjalan dengan lancar sesuai dengan RPP.

Pada siklus 2, masih menggunakan sistem Flipped classroom dan penggunaan edmodo. Dibandingkan siklus sebelumnya, jumlah mahasiswa yang mengerjakan tugas awal siklus II lebih meningkat. Siswa terlihat lebih siap menerima perkuliahan dan suasana kelas lebih aktif dan kondusif dibanding siklus I. Pada siklus ini perbaikan dari siklus sebelumnya seperti setting kelas dengan huruf U, dsb. Secara keseluruhan pelaksanaan do pada siklus 2 berjalan dengan lancar sesuai dengan RPP.

Pada siklus 3, masih menggunakan sistem Flipped classroom dan penggunaan edmodo. Pada siklus ini, semua mahasiswa mengerjakan tugas awal siklus 3 . Dibandingkan dengan siklus kedua, pada siklus ini keaktifan mahasiswa saat berlomba menjawab pertanyaan dari dosen lebih baik. Pertanyaan tidak lagi didominasi oleh satu mahasiswa dalam sebuah kelompok. Secara keseluruhan pelaksanaan do pada siklus 3 berjalan dengan lancar sesuai dengan RPP.

Proses perkuliahan tidak hanya berfokus pada pengembangan aspek kognitif saja, tetapi juga menyentuh aspek efektif dan psikomotor, ditinjukkan oleh bervariasinya aktivitas belajar yang diarahkan oleh dosen melalui praktek langsung di kelas. Terjadi perubahan pola pembelajaran dosen berupa semakin mengurangi penggunaan ceramah dan menambah variasi metode serta 
penggunaan media.

Pelaksanaan pembelajaran sebagai kegiatan open lesson menjadi pengalaman berharga bagi dosen model, dosen observer dan mahasiswa. Pelaksanaan pembelajaran dari siklus 1 sampai siklus 3 menunjukkan adanya kesiapan mahasiswa dalam pembelajaran mandiri yang semakin membaik.

\section{See}

Tahap ini dilakukan setelah pelaksanaan tahap do yang dihadiri oleh dosen model dan observer. Tim berdiskusi mengenai temuan fenomena yang terjadi selama tahap do pada setiap siklus, kemudian dibahas perbaikan apa yang bisa dilakukan pada siklus berikutnya. Secara umum baik dosen model dan dosen observer memperoleh pengalaman berharga dari pelaksanaan perkuliahan dari siklus 1 sampai dengan 3 .

\section{Hasil Angket Tanggapan Mahasiswa}

Angket tanggapan mahasiswa terhadap penerapan Flipped classroom berbantu ICT terhadap kemandirian mahasiswa yang bersangkutan terdiri dari 7 item yang disebar melalui google formulir. Angket ini menjaring tanggapan mahasiswa mengenai proses perkuliahan yang dialami dan dirasakan sendiri oleh mahasiswa selama 3 siklus. Berdasarkan hasil analisis skor tanggapan mahasiswa, 21\% mahasiswa memberikan tanggapan sangat setuju (SS), 60,55\% mahasiswa memberikan tanggapan setuju (S), dan $18,45 \%$ mahasiswa memberikan tanggapan kurang setuju (KS) terhadap aspek pengelolaan diri (self-management); 26,3\% mahasiswa memberikan tanggapan sangat setuju (SS), 57,9\% mahasiswa memberikan tanggapan setuju (S), dan 15,8\% mahasiswa memberikan tanggapan kurang setuju (KS) terhadap aspek keinginan untuk belajar (desire for learning); 31,55\% mahasiswa memberikan tanggapan sangat setuju (SS), 57,9\% mahasiswa memberikan tanggapan setuju (S), dan $10,55 \%$ mahasiswa memberikan tanggapan kurang setuju (KS) terhadap aspek kontrol diri (self-control); dan 26,3\% mahasiswa memberikan tanggapan sangat setuju (SS), 57,9\% mahasiswa memberikan tanggapan setuju (S), dan 15,8\% mahasiswa memberikan tanggapan kurang setuju (KS) terhadap model pembelajaran Flipped classroom berbantu ICT yang diterapkan pada perkuliahan Fotografi Dasar.

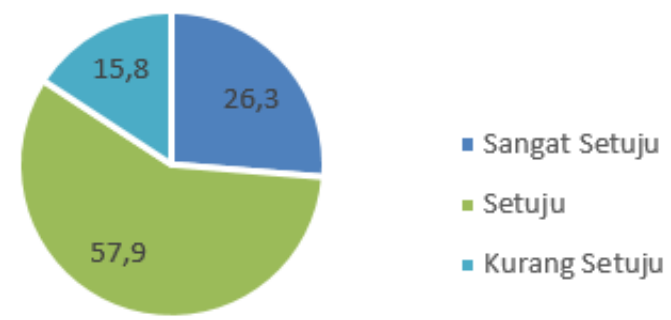

Figure 1. Grafik tanggapan mahasiswa mengenai model pembelajaran Flipped classroom berbantu ICT yang diterapkan pada perkuliahan Fotografi Dasar

\section{CONCLUSION}

Berdasarkan hasil pelaksanaan Lesson Study selama 3 siklus dapat disimpulkan :

1. Suasana perkuliahan menjadi "lebih hidup” ditunjukkan oleh meningkatnya keaktifan belajar mahasiswa selama 3 siklus tersebut.

2. Penerapan Flipped classroom meningkatkan kesiapan mahasiswa dalam mengikuti perkuliahan, yang dapat dilihat dari adanya peningkatan keaktifan dan kesiapan mahasiswa pada setiap siklusnya saat berada pada sesi tanya jawab dan diskusi kelompok.

3. Proses perkuliahan tidak hanya berfokus pada pengembangan aspek kognitif saja, tetapi juga menyentuh aspek efektif dan psikomotor, ditinjukkan oleh bervariasinya aktivitas belajar yang diarahkan oleh dosen melalui praktek langsung di kelas.

4. Terjadi perubahan pola pembelajaran dosen berupa semakin mengurangi penggunaan ceramah dan menambah variasi metode serta penggunaan media.

5. Secara umum, semua dosen yang terlibat baik dosen model maupun dosen observer ada kecenderungan semakin bisa bekerja sama dengan teman sejawat ,semakin terbuka dalam mengemukakan 
kekurangan, dan semakin berkeinginan untuk selalu meningkatkan kualitas pembelajarannya.

6. Tanggapan mahasiswa terhadap penerapan flipped classroom berbantu ICT terhadap kemandirian mahasiswa pada perkuliahan Fotografi Dasar adalah positif, dengan 57,9\% mahasiswa memberikan tanggapan setuju.

\section{REFERENCES}

[1] "Tantangan di Era Revolusi Industri 4.0 Bagi Perguruan Tinggi Indonesia,” May 15, 2018. [Online]. Available: https://www.quipper.com/id/blog/quip per-campus/campus-info/revolusiindustri-4-0/.
[2] I. Ahmad and D. Jenderal, "Proses Pembelajaran Digital dalam Era Revolusi Industri 4.0,” pp. 1-13, 2018.

[3] "Flipped Classroom 'Membalik' Model Pembelajaran Tradisional," August 2, 2013. [Online]. Available: http://guraru.org/info/flippedclassroom-membalik-modelpembelajaran-tradisional/.

[4] T. Dalgleish et al., "Self-Directed Learning with ICT: Theory, Practice, and Assessment," J. Exp. Psychol. Gen., vol. 136, no. 1, pp. 23-42, 2007.

[5] J. M. Read, "Training and Developing Self-directed Learning Through Menitoring, Coaching other Developmental Activities and Opportunities., 2000 